\title{
LANDUSE PATTERN AND ITS CHANGE IN THE EASTERN CHURIYA HILLS OF NEPAL HIMALAYA
}

\author{
Dinesh R. Bhuju, Pralad B. Yonzon and Bidur M. Baidya \\ Resources Himalaya Foundation \\ GPO Box 2448, Kathmandu, Nepal \\ e-mail: ce@resourceshimalaya
}

\begin{abstract}
The Churiya hill range in the Himalaya in eastern Nepal once had $81.0 \%$ of its area $\left(780 \mathrm{~km}^{2}\right)$ as hardwood forest. Our analysis suggests that agricultural land has increased over two-folds, and the forests have decreased at least by $25 \%$. Although 390 villages are there in the study area, the Churiya hills will have to bear more influx of humans. Its steep slopes ( $>40^{\circ}$ in average) has very little to offer for agriculture. However, grow up and spreading of settlements in the fragile landscapes of the Churiya will put both the humans and the natural forests at risk, making landscape-level conservation an arduous task.
\end{abstract}

Key words: Churiya Range, Climat, Forest degradation, GIS, Himalaya, Soil type.

\section{INTRODUCTION}

Nepal (area: 147,181 $\mathrm{km}^{2}$ ) contains five major physiographic zones: Terai, Churiya (Siwalik), Midhills, High Mountain, and the Himalaya (LRMP 1986, HMGN 1989). These physiographic zones run parallel from east to west across the country's $885 \mathrm{~km}$ length and are spread over varying elevations (Fig. 1). The Churiya, also known as Siwaliks, constitute an integral part of the Himalaya in the south. In Nepal, more than $76 \%$ of the Churiya is under forest cover, mainly that of hardwood components such as Shorea robusta and Terminalia spp. This coverage is the highest percentage of land under forest of any physiographic zone in the country. The zone consists of tertiary unconsolidated and highly erodible fluviatile sediments ranging from relatively fine-grained gray wackes in the south (lower Siwalik), through soft of clay (middle Siwalik) to very coarse sands and conglomerates (upper Siwalik) in the north (Carson 1985).
Geologically the Churiya is very rugged and unstable, and its river system exceedingly flashy (Jhingra 1981). As it is regularly affected by soil erosion due to floods and landslides the erosion rate in the Churiya estimated between 780-20,000 tones $\mathrm{km}^{-2} \mathrm{yr}^{-1}$ depending upon land use type (Mishra and Bista 1998).

The Churiya rocks are rich in vertebrate fossil contents. Churiya's unearthed fossils of later Tertiary have provided basis for much of our present knowledge of the evolution of Asian flora and fauna (Itihara et al. 1972). Major fossil fauna includes primates, carnivores, ungulates, elephants, rodents, birds, reptiles and fish. The primate collection from the Churiya formations includes a number of genera of Anthropoids. While fossil parts of prehistoric elephant were recently unearthed, living fossil plants such as tree fern (Cyathia spp.) still occurs the Churiya of east Nepal (Bhuju and Yonzon 2000). 


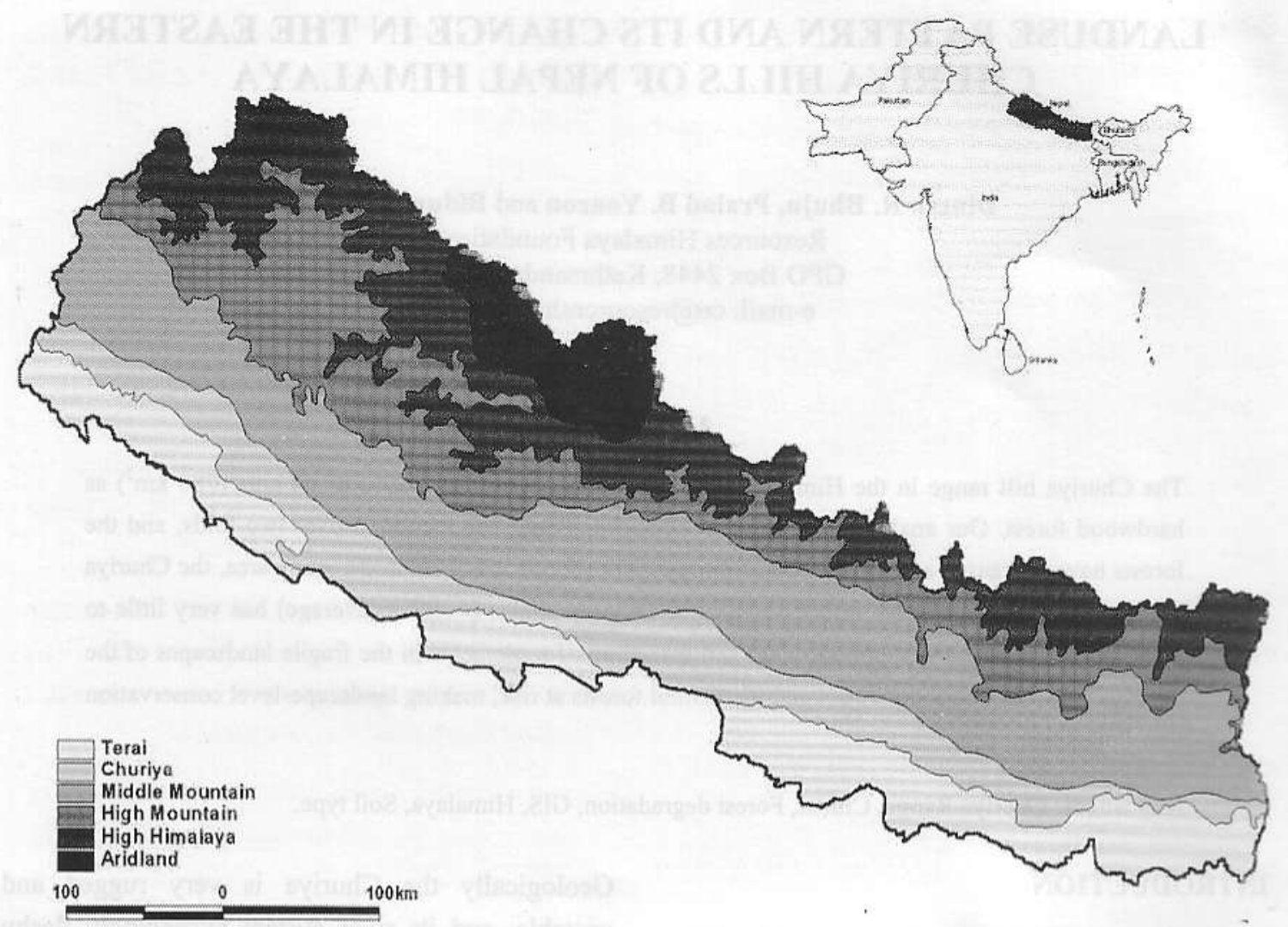

Fig. 1. Six major physiographic zones of Nepal.

Human settlements in the Churiya dates back to 1950 s when the government allowed prime resettlements in forest area for revenue through agriculture. Subsequent malaria eradication and the opening of East-West Highway in the early 1960s and 1970s, many inner valleys of the high mountains had large-scale migration from the hills also opening encroachments in the Churiya . Today, the Terai, along with the Churiya, supports $46.7 \%$ of the total population of Nepal, including human encroachment and their associated disturbances such as livestock grazing (Howell and Epstein 1999) and deforestation.

The present study aims at assessing changes in the land-use pattern since 1958 to understand spatial changes and to identify potential role of the Churiya forest in the context of landscape level conservation.

\section{MATERIALS AND METHODS}

\section{Study area}

The study area is a part of the Churiya in east Nepal $\quad\left(26^{\circ} 40^{\prime} \mathrm{N}-2753^{\prime} \mathrm{N}, \quad 87^{\circ} 08^{\prime} \mathrm{E}-88^{\circ} 11^{\prime} \mathrm{E}\right)$ extending $105 \mathrm{~km}$ from the Mechi River (Nepal's eastern border) to the Saptakoshi River covering a total area of $779.24 \mathrm{~km}^{2}$ (width: $500 \mathrm{~m}-20 \mathrm{~km}$; elevation: $115-1300 \mathrm{~m}$ ). The declination of the Churiya for this study was based on the geological map of eastern Nepal. The Churiya in Nepal is classified into: (a) upper Siwalik, (b) middle Siwalik, and (c) lower Siwalik. The study area included only middle and lower Siwalik. There were 390 villages (settlements) under 37 Village Development Committees (VDC) of the five districts: Jhapa $\left(32.9 \mathrm{~km}^{2}\right)$, Morang $\left(211.3 \mathrm{~km}^{2}\right)$, 
Sunsari $\left(89.4 \mathrm{~km}^{2}\right)$, Ilam $\left(443.9 \mathrm{~km}^{2}\right)$ and Dhankuta $\left(1.8 \mathrm{~km}^{2}\right)$ districts.

\section{Climatological data}

Climatological data suggest that the mean maximum temperature gradually increases from January $\left(21.2^{\circ} \mathrm{C}\right)$ and reach the high in April $\left(33.6^{\circ} \mathrm{C}\right)$ which remain almost same till August $\left(33.0^{\circ} \mathrm{C}\right)$ and decreases from September $\left(32.1^{\circ} \mathrm{C}\right)$. The mean minimum also show similar pattern. April was the driest month with less than $70 \%$ of relative humidity, in the remaining months it remained $>80 \%$ in average. The precipitation is distributed mainly during summer by monsoon and is high in August and September. Our GIS analysis revealed that the mean annual precipitation is not evenly distributed in the Churiya. At least five classes (volume) of rainfall were noticed with the highest precipitation $(>3200 \mathrm{~mm}$ ) in the east near Mechi River and lowest $(<2000 \mathrm{~mm})$ in the west near Saptakoshi River.

\section{Materials}

Three time-series maps of 1958 (scale 1:63,360; Govt. of India 1958), 1978 (scale 1:50,000; LRMP 1986) and 1992 (scale 1:25000; HMGN/FINNIDA 1996) were digitized for GIS (Geographic Information System) analysis using ArcInfo 3.52 and Arcview 3.2. Land-use categories were agriculture, forest, shrub, grazing, barren, and sand/gravel. Information were also assessed for urban area, swamp, tea/coffee plantation, orchard and infrastructure such as canals. For ground truthing, 35 geographic reference points for sampling were ascertained by combined usage of geographic grids using random table (Fig. 2). In the field, the reference points were located with the help of Global Positioning System (GPS $4000 \mathrm{XL}$, Magellan, USA). Field visit recorded that forests of 20 sampling sites were under community management, one was private and the rest 14 were government. Majority of the sites had steep slope.

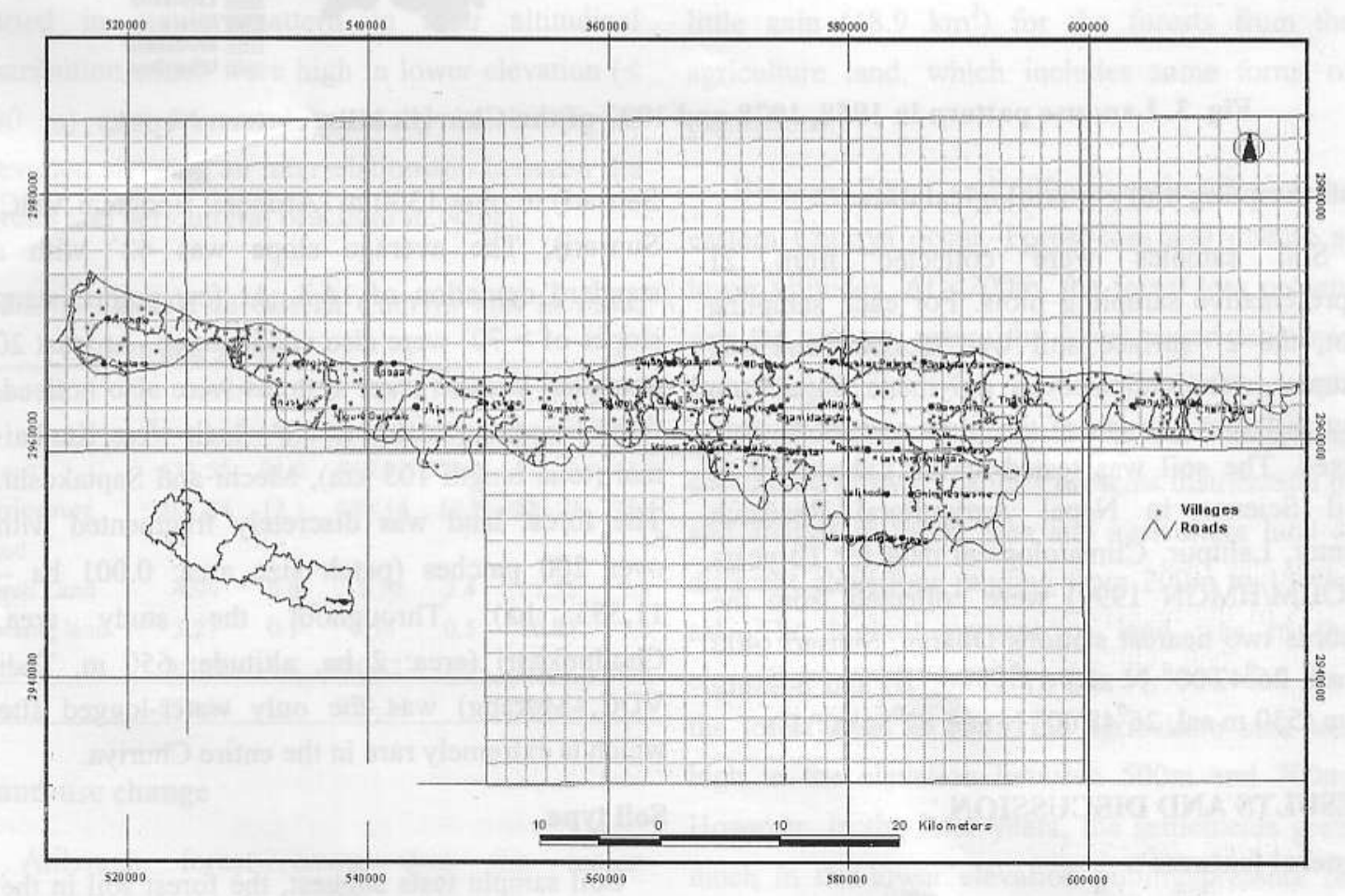

Fig. 2. Geographic reference points (sampling sites) in the Churiya hills, eastern Nepal. 


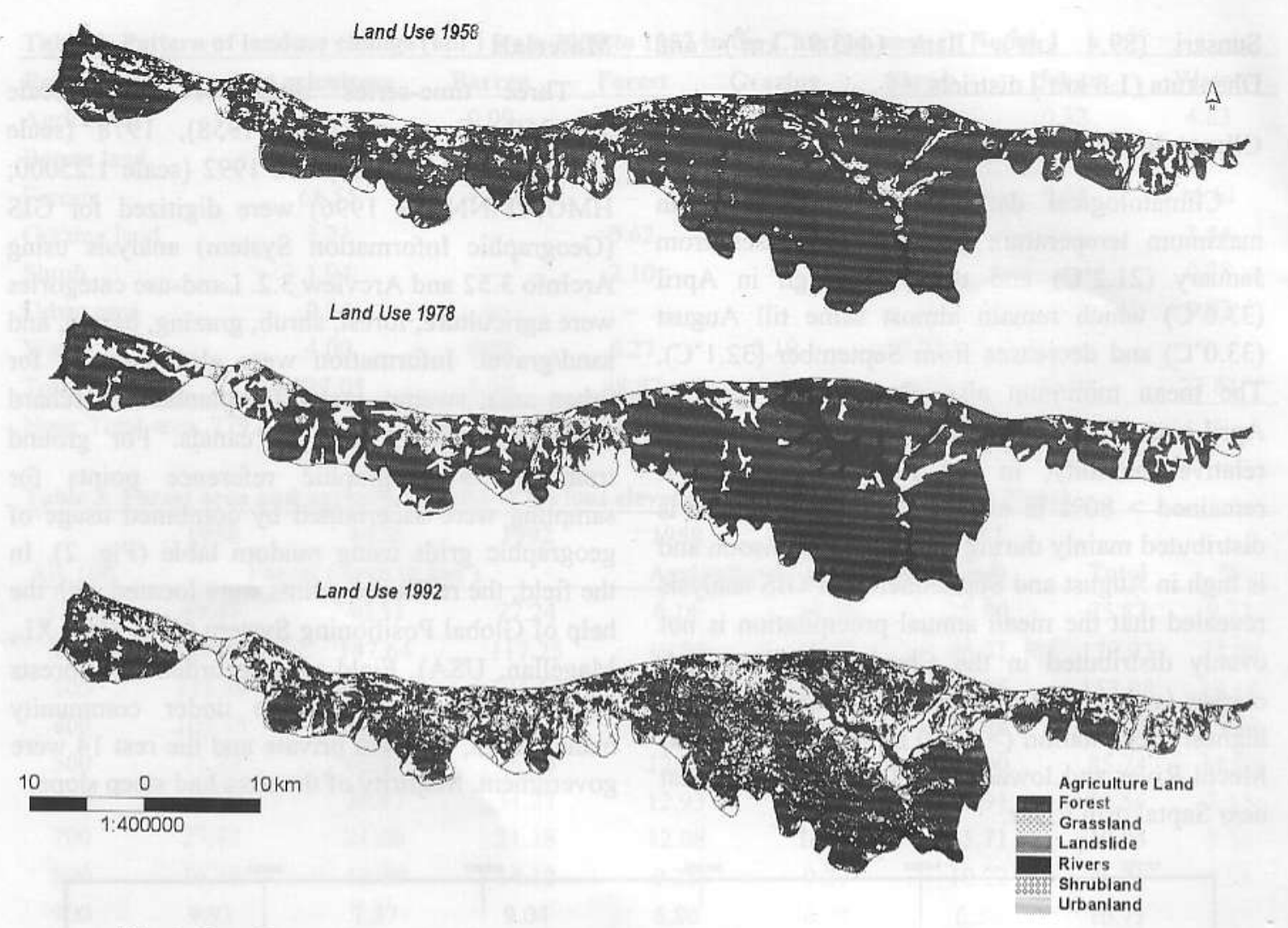

Fig. 3. Landuse pattern in 1958, 1978 and 1992 of the Churiya hills, eastern Nepal.

\section{Soil sampling and climatological data}

Soil samples were collected from 21 representative sampling plots. For each sampling plot, the 2" surface soil was scooped and soil samples were collected in polythene bags from four different corners of the plots and thoroughly mixed. The soil was tested at the Laboratory of Soil Science in Nepal Agricultural Research Center, Lalitpur. Climatological data for 10 years (DOHM/HMGN 1999) were collected from the records two nearest stations Dharan, Sunsari (400 $\mathrm{m}$ asl, $26^{\circ} 47^{\prime} 00^{\prime \prime} \mathrm{N}$ and $\left.87^{\circ} 17^{\prime} 00^{\prime \prime} \mathrm{E}\right)$ and Soktim, Ilam ( $530 \mathrm{~m}$ asl, $26^{\circ} 48^{\prime} 00^{\prime \prime} \mathrm{N}$ and $\left.87^{\circ} 54^{\prime} 00^{\prime \prime} \mathrm{E}\right)$.

\section{RESULTS AND DISCUSSION}

\section{General features}

The elevation of the Churiya in east Nepal varied from $115 \mathrm{~m}$ (Chatara, Barahkshetra VDC,
Sunsari) to over $1300 \mathrm{~m}$ (Arubote, Bhogteni VDC, Sunsari). The average slope was $42^{\circ}$ with a standard deviation of 14.3. At few points, steep slopes of $>70^{\circ}$ were also encountered. At least 20 perennial streams river systems were also noticed, three being the major rivers which were Kankaimai (total length $103 \mathrm{~km}$ ), Mechi and Saptakoshi. The forest land was discretely fragmented with over 200 patches (patch size area: 0.001 ha 11,555 ha). Throughout the study area, Chulipokhari (area: 2 ha, altitude: $650 \mathrm{~m}$, Tadi VDC, Morang) was the only water-logged site which is extremely rare in the entire Churiya.

\section{Soil type}

Soil sample tests suggest, the forest soil in the Churiya of east Nepal was acidic with an average $\mathrm{pH}$ of 5.2. The contents of Nitrogen and Organic 
Matter were very low which were $0.1 \%$ and $2.5 \%$ respectively in average. Very few samples $(<10 \%)$ showed high percent of Nitrogen and Organic Matter. The soil contained $62.7 \%$ of sand, $28.7 \%$ of silt and $9.0 \%$ of clay. Over $90 \%$ of the sampling plots had sandy loam type of soil.

\section{Landuse pattern}

We analyzed changes in landuse pattern in 1957, 1978 and 1992, respectively (Fig. 3). A major land in the eastern Churiya was still occupied by forests with an area of $477.28 \mathrm{~km}^{2}$ covering $61.25 \%$ of the total area $\left(779.24 \mathrm{~km}^{2}\right)$ and agriculture land was $221.71 \mathrm{~km}^{2}$ (28.45\%) (Table 1). Sand and gravel covered nearly $6.0 \%$ indicating the presence of a large network of rivers and streams. Shrub and grazing land occupied 1.5\% each, and the rest land-use including urban area made $1.5 \%$. Both the forests and agriculture lands varied in similar pattern in their altitudinal distribution which were high in lower elevation (< $300 \mathrm{~m}$ ) and decreased gradually in the higher elevation showing an interrelationship between the forests and agricultural practices in Nepal.

Table 1. Landuse in eastern Churiya hills in 1958, 1978 and 1992.

\begin{tabular}{lccccccc}
\hline Landuse & \multicolumn{2}{c}{1958} & \multicolumn{2}{c}{1978} & \multicolumn{2}{c}{1992} \\
& Area km & $\%$ & Area km $\mathbf{~ k m}^{2}$ & $\%$ & Area km & $\%$ \\
\hline Forest & 631.55 & 81.0 & 568.02 & 72.9 & 477.23 & 61.2 \\
Agriculture & 101.84 & 13.1 & 138.14 & 17.7 & 221.71 & 28.5 \\
Land & & & & & & \\
Shrub Land & 4.96 & 0.6 & 18.70 & 2.4 & 11.52 & 1.5 \\
Grazing land & 5.27 & 0.7 & 3.56 & 0.5 & 10.87 & 1.4 \\
Others & 35.62 & 4.6 & 50.82 & 6.5 & 53.12 & 6.8 \\
\hline Total & 779.24 & & 779.24 & & 779.24 & \\
\hline
\end{tabular}

\section{Land-use change}

Although forest cover was the major component of the Churiya in east Nepal, it has decreased by over $25 \%$ in less than 35 years. In 1958 , the total area of the forests in the Churiya was $631.6 \mathrm{~km}^{2}$ sharing $81.0 \%$ of the total area. By 1978 , it decreased by $10 \%$ or an area equivalent to $63.5 \mathrm{~km}^{2}$. In 1992, it further deteriorated and the forests shrunk to a total area of $477.2 \mathrm{~km}^{2}$. During the same period, the agriculture land had increased by more than $120 \%$, i.e. from a total area of 101.8 $\mathrm{km}^{2}$ in 1958 to $221.7 \mathrm{~km}^{2}$ in 1992 . Also, increment in agriculture land was high comparatively between 1978-1992 than 1958-1978 (Table 1).

While the highest gain was for agriculture with $127.1 \mathrm{~km}^{2}$ or $56 \%$ of the total changed area, and a marginal change for urban area with a gain less than $0.1 \%$ of the total changed area (Table 2). The highest conversion for the increase in agriculture land came from the forests contributing $106.2 \mathrm{~km}^{2}$ (83.5\%). Similarly, grazing land and shrub land had increased during the period at the expense of forests. On the other hand, there was a little gain $\left(48.9 \mathrm{~km}^{2}\right)$ for the forests from the agriculture land, which includes some forms of plantations.

Between $200 \mathrm{~m}$ and $600 \mathrm{~m}$, nearly $60 \%$ of the eastern Churiya occur. Forest loss was intense at lower altitudes. At $<200 \mathrm{~m}$, the forest loss percent was the highest, where the forest cover decreased from $65.24 \%$ (1958) to $35.93 \%$ (1992). This could be attributed to accessibility in low land, and population growth. Table 3 presents distribution of and change in forest area and agriculture land at different elevations ranging from $200 \mathrm{~m}$ to $1300 \mathrm{~m}$ asl. The highest percent of land was in the elevations of $200 \mathrm{~m}-400 \mathrm{~m}$ with $58.38 \%$, and also the forest area. In 1958, the agriculture land was high in the elevation between $500 \mathrm{~m}$ and $700 \mathrm{~m}$. However, in the later years, the settlements grew much in the lower elevation putting pressure on forests. In 1992, the agriculture land increased by three folds in these elevations. 
Table 2. Pattern of landuse change $\left(\mathrm{km}^{2}\right)$ from 1958 to 1992 in the Churiya, eastern Nepal.

\begin{tabular}{lccccccc}
\hline From/To & Agriculture & Barren & Forest & Grazing & Shrub & Urban & Water \\
\hline Agriculture & - & 0.09 & 27.11 & 0.44 & 3.93 & 0.32 & 4.83 \\
Barren land & 0.33 & - & 1.18 & - & 0.04 & 0.06 & - \\
Forests & 65.55 & 1.24 & - & 2.93 & 14.36 & 0.01 & 15.61 \\
Grazing land & 1.21 & - & 0.62 & - & - & - & 3.44 \\
Shrub & 1.94 & - & 2.10 & - & - & - & 0.78 \\
Urban area & 0.14 & - & - & - & - & - & 0.02 \\
Water & 4.00 & 0.08 & 6.27 & 0.19 & 0.22 & - & - \\
Total & 127.05 & 5.99 & 48.87 & 10.76 & 10.02 & 0.20 & 23.84 \\
\hline
\end{tabular}

Note: Total area: $779.24 \mathrm{~km}^{2}$; Unchanged area: $619.23 \mathrm{~km}^{2}$

Table 3. Forest area and agriculture land in various elevation in Churiya hills, eastern Nepal.

\begin{tabular}{|c|c|c|c|c|c|c|c|c|}
\hline \multirow[b]{2}{*}{ Alt. (m) } & 1958 & 1978 & 1992 & 1958 & 1978 & 1992 & \multirow[b]{2}{*}{ Total } & \multirow[b]{2}{*}{$\%$} \\
\hline & \multicolumn{3}{|c|}{ Forest (Area in $\mathrm{km}^{2}$ ) } & \multicolumn{3}{|c|}{ Agriculture Land (Area in $\mathrm{km}^{2}$ ) } & & \\
\hline$<200$ & 49.47 & 40.31 & 27.24 & 6.14 & 14.38 & 25.80 & 75.82 & 9.73 \\
\hline 200 & 159.18 & 147.64 & 117.25 & 10.89 & 18.82 & 46.51 & 179.93 & 23.09 \\
\hline 300 & 135.89 & 126.94 & 104.65 & 9.43 & 17.10 & 35.05 & 153.08 & 19.65 \\
\hline 400 & 105.75 & 98.90 & 83.76 & 11.83 & 18.22 & 28.84 & 121.88 & 15.64 \\
\hline 500 & 71.33 & 66.01 & 56.16 & 12.28 & 15.53 & 22.90 & 85.74 & 11.00 \\
\hline 600 & 41.68 & 36.47 & 31.27 & 12.93 & 14.71 & 19.91 & 55.56 & 7.13 \\
\hline 700 & 27.47 & 21.60 & 21.18 & 12.08 & 14.01 & 15.71 & 40.04 & 5.14 \\
\hline 800 & 16.79 & 12.70 & 14.12 & 9.28 & 9.37 & 10.22 & 26.21 & 3.36 \\
\hline 900 & 9.91 & 7.37 & 9.04 & 6.80 & 6.39 & 6.59 & 16.71 & 2.14 \\
\hline 1000 & 6.53 & 4.97 & 5.81 & 4.91 & 4.81 & 4.85 & 11.44 & 1.47 \\
\hline 1100 & 4.43 & 3.24 & 4.00 & 3.72 & 3.25 & 3.79 & 8.14 & 1.05 \\
\hline 1200 & 2.23 & 1.41 & 2.11 & 1.32 & 1.29 & 1.24 & 3.55 & 0.46 \\
\hline 1300 & 0.89 & 0.48 & 0.67 & 0.22 & 0.25 & 0.30 & 1.12 & 0.14 \\
\hline Total & 631.55 & 568.03 & 477.28 & 101.84 & 138.14 & 221.71 & 779.24 & 100.00 \\
\hline
\end{tabular}

\section{CONCLUSION}

Of all five physiographic zones in Nepal, the Churiya has the highest percent of forested land in terms of landuse though it shares the least percent area $(<13.0 \%)$ of the country's total area. The fertile Terai had shadowed the Churiya, and human encroachment with ineffective management of the forests resources in the recent years have brought a drastic changes. Even though the arable land is very limited for its steep features, in-migration in the Churiya is increasing. Human settlements are expanding to the vicinity of the forests of the fragile landscape putting both the human lives and the natural resources at risk. Given the rapid fragmentation of forest areas, landscape-level conservation in east Nepal with reference to the eastern Himalaya may hinge on how early and effective initiatives are implemented.

\section{ACKNOWLEDGMENTS}

The Landuse maps 1958 were provided by the Department of Forests, HMGN. The second author was the recipient of Pro Natura Fund of the Nature Conservation Society, Japan. Authors extend their thanks to Prof. M. Ohsawa, University of Tokyo and Dr. T. Nakamura for their help to carry out the study. 


\section{REFERENCES}

Bhuju, D. and P. Yonzon. 2000. Floristic composition, forest structure and regeneration of the Churiya forests, eastern Nepal. In: Ecology of the Nepal Churiya, (Part I: MechiSaptakoshi) (eds.) Yonzon, P. and D. Bhuju. Resources Himalaya, Kathmandu, pp. 24-52.

Carson, B. 1985. Erosion and sedimentation processes in the Nepal Himalaya. ICIMOD Occasional Paper 1. International Centre for Integrated Mountain Development, Kathmandu.

DOHM/HMGN. 1999. Climatological Records of Nepal. Department of Hydrology and Meteorology, His Majesty's Govt. of Nepal, Kathmandu.

GOI. 1958. Indian Survey Map 1958. Survey of India Offices, Govt. of India.

HMGN. 1989. Forestry Sector Master Plan for Nepal 1989. His Majesty's Govt. of Nepal, Kathmandu, pp. 292.
HMGN/FINNIDA. 1996. Landuse Map 1992. His Majesty's Govt. of Nepal / Govt. of Finland, Kathmandu.

Howell, J.H. and D.M. Epstein. 1999. Protection of Siwalik land. Banko Janakari. 3:43-45.

Itihara, M., S. Tatsuo and M. Noboru. 1972. Photogeological survey of the Siwalik ranges and Terai plains, southeastern Nepal. J. Geosciences, Osaka Univ. 15:77-98.

Jhingra, A.G. 1981. Geology of the Himalaya. In: The Himalaya. (ed.) J.S. Lall. Oxford University Press, Oxford, pp. 77-98.

LRMP. 1986. Landuse Map 1978. Land Resources Mapping Project. Dept. of Forests, His Majesty's Govt. of Nepal / Govt. of Canada / Keating Earth Sciences, Kathmandu.

Mishra, S.B. and S. Bista. 1998. Soil erosion. In: A Compendium on Environment Statistics 1998 Nepal. His Majesty's Govt. of Nepal, National Planning Commission Secretariat, Central Bureau of Statistics, Kathmandu, pp. 349-358. 